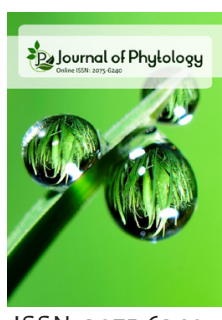

ISSN: $2075-6240$

Received: January 11, 2019

Accepted: March 15, 2019

Published: March 20, 2019

*Corresponding Author:

K. Arunkumar

Email: arunkru9791402135@

gmail.com

\section{Seed priming technology in spice crops: A review}

\author{
K. Arunkumar*, V. Jegadeeswari, C. Ushamalini \\ Department of Spices and Plantation Crops, Horticultural College and Research Institute, Tamil Nadu Agricultural \\ University, Coimbatore, 641003, Tamil Nadu, India
}

\begin{abstract}
Seed priming is one of the important method of seed treatment is the process of controlled hydration of seeds. At the time to a level that permits the pre-germinative metabolic activity, but that prevents actual emergence of the radicle is also known as pre germination seed treatment method. Seed priming is useful for increase the speed of seed germination and uniformity of germination particularly under adverse conditions like temperature, moisture and salinity. Seeds are soaked in different solutions like various inorganic salts, sugars and polyethylene glycol (PEG) a chemically inert, high molecular weight compounds, etc. After seed priming increase in hydrolytic enzyme activity especially $\alpha$-amylase, strong increase of super oxide dismutase, catalase activities and expression of certain proteins related to water stress and heat shock. During germination the primed seeds contain higher scavenging of ROS (Reactive Oxygen Species). This reviews reported the primed spices seeds or rhizomes contain abiotic stress tolerant capacities, increase the antioxidant enzyme activities like peroxidase, catalase, superoxide dismutase (SOD), polyphenol oxidase (PPO), lipoxygenase (LOX) and phenyl alanine ammonia lyase (PAL), break the seed dormancy, increase the germination percentage and early growth. This studies gives an overview about the seed priming in spice crops with relevant case studies.
\end{abstract}

KEYWORDS: Seed priming, polyethylene glycol, $\alpha$-amylase, ROS

\section{INTRODUCTION}

Seed treatment is a method treat the seedsto improve the germination and vigour potential and as well as to maintain the health of the seed. Pre sowing seed treatments includes the following a) Chemical treatments to improve germination and vigour potential, b) Insecticidal and fungicidal treatment, c) Special treatments like Seed hardening, Seed Fortification, Moist sand conditioning, Seed pelleting, Seed infusion, Osmotic priming, Fluid drilling, Separation of viable seeds [1]. Seed priming is one of the method of seed treatment is the process of controlled hydration of seeds. At the time to a level that permits the pre-germinative metabolic activity, but that prevents actual emergence of the radicle is also known as pre germination seed treatment method [2]. Seed priming is useful for increase the speed of seed germination and uniformity of germination particularly under adverse conditions like temperature, moisture and salinity. Seeds are soaked in different solutions like various inorganic salts, sugars and polyethylene glycol (PEG) a chemically inert, high molecular weight compounds, etc. The temperature suggested during priming is between $10^{\circ} \mathrm{C}-15^{\circ} \mathrm{C}$. The duration of priming varies with the crop from 1 day to
23 day. After priming the seeds are redried to original moisture content [3].

\section{METHODS OF SEED PRIMING}

Heydecker et al. [4] used different terms depends upon the methods adopted for priming. Different methods are commonly used for priming like Osmopriming, in which the seeds are soaked in osmotic solutions like Polyethylene glycol (PEG) [5], halopriming, in which seed will be soaked in salt solutions [6], hydropriming, in which the seeds are soaking in water [7]. Apart from these, solid matric priming is another technique, which consists of mixing seeds with an organic or inorganic carrier and water for a period of time [8]. During priming the water is largely held by the carrier and the seed water potential is regulated by the matric potential of the seed. At the time the seeds can imbibe water from the carrier till the equilibrium is reached. Taylor et al. [9] introduced the word solid matric priming (SMP), in which a solid matric instead of an osmotic solution is employed. According to Khan [10] solids used for matrix priming should have i) a proportionately high matric to osmotic component capacity ii) negligible water

Copyright: ( ) The authors. This article is open access and licensed under the terms of the Creative Commons Attribution License (http://creativecommons.org/licenses/by/4.0/) which permits unrestricted, use, distribution and reproduction in any medium, or format for any purpose, even commercially provided the work is properly cited. Attribution - You must give appropriate credit, provide a link to the license, and indicate if changes were made. 
soluble capacity iii) low chemically reactive capacity iv) high water holding capacity v) different particle size, structure and porosity vi) huge surface area viii) maximum bulk value and maximum bulk density and viii) ability to adhere to seed surfaces. These characters of the solid matric system actually minimize aeration problems. Biopriming involves coating the seeds with biological agents like bacteria and soaking in warm water until the seed moisture content increased to $35-40 \%$ and redrying [11]. Drum priming is misting of seed with water and redrying before they complete germination. Seeds are rotated inside of the drum with specific amount of water provided as a fine mist [12].

\section{Mode of action}

The followed mode of action is occur during seed germination. The seed priming responsible for the seed germination mechanism have been discussed by several workers [13].

i. Seeds complete phase I and II of germination, and only require a favourable condition for water uptake in order to begin radical growth [14]. Phase I called as hydration phase and phase II called as lag phase. This situation is therefore more comparable to that of pre-germinated seeds in that the hydrated, primed seeds enter immediately into phase III of imbibitions (growth).

ii. At the time of seed drying the rearrangement of cell membrane structure is lost and increase in membrane integrity is present $[15,16]$.

iii. Damage to nucleic acids is repaired and proteins are acquired during the seed storage $[17,18]$.

iv. Higher respiration and ATP production [19].

v. Increase in hydrolytic enzyme activity especially $\alpha$-amylase [20] and strong increase of super oxide dismutase and catalase activities [21].

vi. Expression of certain proteins related to water stress and heat shock.

vii. Increased B- tublin accumulation in the radicle tip during priming.Tublin is the main functional protein of microtubules, which is necessary for mitotic spindle formation.

viii.Accumulation of more sugar which could readily support metabolic activity [22], leading to faster seedling emergence.

ix. Increase in UDP glucose, which plays central role in production of nucleotide sugars.

$\mathrm{x}$. Increased the DNA content at the time of seed germination as a result of activation or synthesis of several useful enzymes of nucleic acid or both.

xi. Increase in total amount of RNA and protein synthesized is present at the time of seed germination [23].

xii. Higher scavenging of AOS (active oxygen species) during seed germination.

\section{Physiological events during priming}

\section{Protein synthesis}

The Protein are synthesized during priming and are increased depends upon the subsequent seed germination compared with the levels seen in untreated controls that means unprimed seeds, while the activities of several germination associated enzymes have been reported to be increased depends upon seed germination after priming [24,25].

It is observed that conditions of priming closely parallel to that of germination allowed the solubilization of 11-S globulin storage protein, is beneficial responsible of seed germination. It is occur into phase II of seed germination process. Many workers have reported increased hydrolytic enzyme activity induced by priming. Berrice and Dearman (1971) [26] in oats an increase in alpha-amylase activity was noted. Increase in $\beta$-tublin in the radicle tip has been observed during the seed priming by Bino et al. (1992) [6]. Tublin is the main functional protein of microtubules which is necessary for mitotic spindle formation.

\section{Seed repair}

The seed priming process can improve the seed germination, at the time seeds should be repaired. The following events occur during seed germination like repair damaged nucliec acid, repair damaged proteins and mitochondria. The seed priming are not only attributable to repair, since newly harvested musk-melon seeds are showed great improvement in seed performance following osmopriming [27].

\section{Recent technology in seed priming}

BSN (Bio-Engineered Supplements and Nutrients) is a worldleading RLF technology. It is a seed priming of fertilizer with a Seed Delivery System (SDS). It causes to rapidly uptake of fertilizer nutrients directly inside the seed. It also eliminates the seed variability of critical essential elements needed in germination and causes early growth, uniform germination and higher seed vigour index than the control unprimed seeds. Once imbibe the nutrients it elevates the vital nutrients to an optimum level and sets the plant for maximum strength for facing any abiotic stress and yield potential than unprimed seeds. The BSN primed seeds are somewhat resistant to abiotic stress condition like salt and drought condition [28].

UV radiation priming - The seeds are primed with UV radiation. It causes change of genetic response materials. The UV radiation primed seeds are more for abiotic stress tolerance in crop plants [29].

\section{Seed priming in spice crops}

Seed priming in spice crops like Cardamom, Ginger, Turmeric, Seed spices. The primed spices seeds or rhizomes contain abiotic stress tolerant capacities, increase the antioxidant enzyme activities like peroxidase, catalase, superoxide dismutase (SOD), polyphenol oxidase (PPO), lipoxygenase (LOX) and phenyl alanine ammonia lyase (PAL), break the seed dormancy, increase the germination percentage and early growth. 


\section{Ginger}

Ghosh (2015) [30] reported the seed rhizomes of ginger are primed with salicylic acid (SA-5 mM). The salicylic acid induce the defense related enzymes like peroxidase, polyphenol oxidase (PPO), lipoxygenase (LOX) and phenyl alanine ammonia lyase (PAL) activities. These enzymes should induce the salicylic acid acquired resistance (SAR) induction for resistance to pythium infection in ginger.

\section{Turmeric}

Boominathan and Sivakumar (2012) [31] reported the seed rhizomes are primed with native PGPR (Plant Growth Promoting Rhizobacteria) like Azospirillumlipoferum, Pseudomonas fluorescens is used for increase the germination percentage, root length, shoot length, dry matter production and vigor index. Not only for induce germination and also induce antioxidant enzymes like peroxidase, catalase and superoxide dismutase activities. These enzymes much helpful for induce the pathogen defense mechanism.

\section{Seed spices}

In seed spices are treated with primed solution to increase the germination percentage, early germination, seed vigor index and also seed yield. The seed priming is increase the seed yield and quality. Aymen and Cherif (2013) [32] in coriander seeds are primed with $\mathrm{NaCl}$ and $\mathrm{CaCl}_{2}$ solutions. These primed solutions increase the uniform germination, plant height, shoot fresh weight and shoot dry weight. The halopriming solutions should induce the resistance to salt stress.Abdoli(2014) [33] reported the fennel seeds are primed with PEG solutions to increase the plumule length, radicle length, seedling length, seedling fresh mass and seedling dry mass production. Mahdavi and Rahimi (2013) [34] reported under salt stress condition the ajowan seeds are primed with chitosan solution to improve the germination and growth. Chitosan is a one of the polysaccharide biopolymer derived from chitin. It is a chitin product. It is not only stimulates growth of plant and also increases the crop yields but also alleviates the harmful effect of abiotic stress on plant growth during stress condition. The chitosan improve the growth parameters like germination percentage, germination rate, seedling vigour index, hypocotyl length, radicle length, dry hypocotyl weight, dry radicle weight and also resistant to salt stress. Saxena et al (2015) [35] reported hydro-matrix seed priming is usefulness in cumin (Сuminu mсуminum L.) for hastening the seed germination. Bahram (2010) [36] reported seed priming with iron and boron enhances germination and yield of dill (Anethumgraveolens). The priming treatment like Fe $(1.5 \%)+\mathrm{B}(1 \%)$ to increase the germination percentage (98\%), seed yield $\left(855 \mathrm{~kg} \mathrm{ha}^{-1}\right)$, essential oil concentration $(2.74 \%)$ and essential oil yield $\left(23.431 \mathrm{ha}^{-1}\right)$.

\section{CONCLUSION}

The seed priming process useful for increase seed germination, early growth, biotic and abiotic stress tolerant, antioxidant capacities, increase yield, break the dormancy. The future thrust area of this review paper is Seed priming for increase yield and oil content in spice crops, practiced in advanced technology.

\section{REFERENCES}

1. Jegathambal R. Pre-sowing seed treatment to augment productivity of sorghum cv. CO 26 under rainfed agriculture (Doctoral dissertation, Tamil Nadu Agricultural University; Coimbatore).1996.

2. Ashraf M, Foolad MR. Pre-sowing seed treatment-A shotgun approach to improve germination, plant growth, and crop yield under saline and non-saline conditions. Advances in agronomy. 2005 Jan 1; 88:223-71.

3. Umarani R, Vigneshwari R. Seed priming. Seed quality enhancement: principles and practices. 2010 Jul 1:118.

4. Heydecker W. Germination of an idea: The priming of seeds University of Nottingham. School of Agriculture Rep., 1973; 1973/74.

5. Farooq MS, Basra SM, Saleem BA, Nafees M, Chishti SA. Enhancement of tomato seed germination and seedling vigor by osmopriming. Pak. J. Agri. Sci. 2005;42: 3-4.

6. Nawaz J, Hussain M, Jabbar A, Nadeem GA, Sajid M, Subtain MU, Shabbir I. Seed priming a technique. International Journal of Agriculture and Crop Sciences. 2013 Nov 24; 6(20):1373.

7. Moradi A, Younesi O. Effects of osmo-and hydro-priming on seed parameters of grain sorghum (Sorghum bicolor L.). Australian Journal of Basic and Applied Sciences. 2009; 3(3):1696-700.

8. Parera CA, Cantliffe DJ. Presowing seed priming. Horticultural reviews. 1994 Jul 28; 16(16):109-41.

9. Taylor AG, Klein DE, Whistlow TH. SMP solid matrix priming of seeds. Scientia Hort., 1988; 37: 1-11.

10. Khan AA. Preplant physiological seed conditioning. Hort. Rev., 1992; 13: 131-181.

11. Cantliffe DJ. Seed enhancements. InIX International Symposium on Timing of Field Production in Vegetable Crops 6072001 May 20 (pp. 53-59).

12. Rowse HR, inventor; National Research Development Corp UK, assignee. Methods of priming seed. United States patent US 5,119,589. 1992 Jun 9.

13. Taylor AG, Allen PS, Bennett MA, Bradford KJ, Burris JS, Misra MK Seed enhancements. Seed science research. 1998 Jun; 8 (2):245-56.

14. Finch-Savage WE, Leubner-Metzger G. Seed dormancy and the control of germination. New phytologist. 2006 Aug; 171(3):501-23.

15. Knyple JS, Janas KM, Radzziwonoska-Jozwiak A. Is enhanced vigor in soybean (Glycine max) dependent on activation of protein turnover during controlled hydration of seed Physiol. Veg., 1980; 18 (1): 157-161.

16. Simon EW, Raja Harun RM. Leakage during seed imbibitions. J.Exp. Bot. 1972; 23(7): 1076-1085.

17. Bino RJ, DeVries JN, Kraak HL, Van Pijlen JG. Flow cytometric determination of nuclear replication stages in tomato seeds during priming and germination. Ann. Bot., 1992; 69: 231-236.

18. Burgass RW, Powell AA. Evidence for repair processes in the invigouration of seeds by hydration. Ann. Bot., 1984; 53: 753-757.

19. Mazor L, Perl MK, Negloi M. Changes in some ATP-dependent activities in seeds during treatment with polyethylene glycol and during the redrying process. J. Exp. Bot., 1984; 35: 1119-1127.

20. Wilson AM. Amylase synthesis and stability in crested wheat grass seeds at low water potentials. Pl.Physiol, 1971; 48: 541-546.

21. Bailly C, Benamar A, Corbineau F, Come D. Antioxidant systems in sunflower (Helianthus annuus L.) seeds as affected by priming. Seed Sci. Res., 2000; 10: 35-42.

22. Sung FJM, Chang YH. Biochemical activities associated with priming of sweet corn seeds to improve vigor. Seed Sci. \& Technol., 1993: 21: 97-105.

23. Khan AA, Tao KL, Knypl JS, Borkowska B, Powell LE. Osmotic 
conditioning of seeds: physiological and biochemical changes. Acta Horti. 1978; 83: 267-278.

24. Fu JR, Lu XH, Chen RZ, Zhang BZ, Liu ZS, Cai DY. Osmopriming of peanut (Arachis hypogaea L.) seeds with PEG to improve vigor and some biochemical activities. Seed Sci. \& Technol., 1988; 16: 197-212.

25. Bray CM, Davison PA, Ashraf M, Taylor RM. Biochemical changes during osmopriming of leek seeds. Ann. Bot., 1989; 63: 185-193.

26. Berrie AMM, Drennan DSH. The effect of hydration - dehydration on seed germination. New Phytol, 1971; 70: 135-142.

27. Welbaum GE, Bradfod KJ. Water relations on seed development and germination in muskmelon (Cucumis melo L.) VI. Influence of priming on germination responses to temperature and water potential during seed development. J. Expt. Bot., 1991; 42: 393-399.

28. BSN seed priming, Available from: http://seedprimer. ruralliquidfertilisers.com/ [Last accessed on 2019 March 15].

29. UV radiation priming seed priming, Available from: https://www. sciencedirect.com/science/article/abs/pii/S009884721730071. [Last accessed on 2019 March 15].

30. Ghosh R. Enzymatic Responses of Ginger Plants to Pythium Infection after SAR Induction. J Plant Pathol Microb, 2015; 6: 283.
31. Boominathan U, Sivakumar PK. Effect of Seed Priming with Native PGPR on its Vital Seedling and Antioxidant Enzyme Activities in Curcuma longa (L.) International Journal of Pharmaceutical \& Biological Archives. 2012; 3(2):372-376.

32. Elouaer Mohamed Aymen, Hannachi Cherif. Influence of seed priming on emergence and growth of coriander (Coriandrum sativum L.) seedlings grown under salt stress. Acta agriculturae Slovenica, 2013; 101: 41-47.

33. Abdoli. Effect of seed priming on seed dormancy, vigor and seedling characteristics of fennel Foeniculum vulgare. Acta Advances in Agricultural Sciences, 2014; 8: 18-24.

34. Mahdavi, Rahimi. Seed priming with chitosan improves the germination and growth performance of ajowan (Carum copticum) under salt stress. Eurasia J Biosci, 2013; 7: 69-76.

35. Saxena SN, Kakani RK, Sharma LK, Agrawal D, Rathore SS. Usefulness of hydro-matrix seed priming in cumin (Cuminum cyminum L.) for hastening germination. International J. Seed Spices, 2015; 5(1): 24-28.

36. Bahram. Seed priming with iron and boron enhances germination and yield of dill (Anethum graveolens). Turk J Agric, 2012; 36: 27-33. 